\title{
How top exporters compete? Evidence from Spain
}

\author{
Juan de Lucio $^{1} \bullet$ Raúl Mínguez $^{1} \bullet$ Asier Minondo $^{2 *} \cdot$ Francisco Requena $^{3}$ \\ ${ }^{1}$ University of Nebrija, Spain \\ ${ }^{2}$ Deusto Business School, Spain \\ ${ }^{3}$ Universitàt de Valencia, Spain
}

Received: 22 February 2018

Revised: 9 May 2018

Accepted: 10 May 2018

\begin{abstract}
This paper analyzes whether top exporters follow a cost-based or a quality-based strategy. Using Spanish firm-level export data for 2016, we show that firms that set lower export prices have larger export revenues. We also find that exporters obtain larger revenues from their lowprice products than from their high-price products. Some results suggest that the negative effects of a higher export price on export revenues can be attenuated if firms export goods that provide scope for quality-differentiation.
\end{abstract}

Keywords: exporters; Spain; exports; export price; cost; quality; strategy

JEL Classification Codes: F14

\section{Introduction}

Porter (1980) argued that firms can pursue three different generic strategies to outperform their competitors: (i) cost leadership, (ii) differentiation and (iii) focus. The workhorse model of international trade with firm-heterogeneity, Melitz (2003), adopts Porter's first generic strategy: More productive firms produce cheaper goods and achieve larger export revenues.

However, some evidence does not fit well with this model's predictions. As explained by Baldwin and Harrigan (2011), if more productive firms competed in prices, we would expect a negative relationship between product prices and distance to market. Since trade costs are larger for distant markets, only the most productive firms, which set lower prices, will obtain the profits to cover those greater costs. Instead, Baldwin and Harrigan (2011) find a positive association between (free-on-board) export prices and distance to markets. ${ }^{1}$

To explain the positive association between distance and export prices, Baldwin and Harrigan (2011) lean towards Porter's second generic strategy: Differentiation. These authors argue that more productive firms manufacture high-quality goods. Profits increase with the quality of the

\footnotetext{
*Corresponding author. E-mail: aminondo@deusto.es.

Citation: de Lucio, J., Mínguez, R., Minondo, A., and Requena, F. (2018) How top exporters compete? Evidence from Spain, Economics and Business Letters, 7(2), 55-61.

${ }^{1}$ This positive correlation has been confirmed by later studies using firm-level data (Bastos and Fernandes, 2011; Martin, 2012; Manova and Zhang, 2012; Harrigan et al., 2015, Görg et al., 2017).
} 
goods, and high-quality goods demand more expensive inputs, or a larger amount of labor. Therefore, quality is correlated with a higher export price, and a larger export price is positively associated with bigger export revenues. ${ }^{2}$

Since both models are based on sensible assumptions, whether top exporters follow a costbased or a quality-based strategy can only be answered empirically. The contribution of this paper is to shed empirical light to this debate analyzing whether Spanish top exporters follow a cost-based or a quality-based strategy. Using firm-level data for 2016, and introducing detailed controls for differences across firms, products and destinations, we find that (i) large export revenues are associated with lower export prices; and (ii) firms exporting multiple products obtain larger export revenues in their low-price products than in their high-price products. Therefore, our empirical evidence suggests that top Spanish exporters follow a cost-based strategy to succeed in foreign markets.

\section{Methods}

In this paper we use regression analyses to test two hypotheses: (i) large export revenue firms compete in costs; and (ii) firms obtain larger export revenues from their low-price products. To test the first hypothesis, we estimate the following equation:

$$
\ln x_{f k d}=\beta \ln p_{f k d}+\gamma_{k d}+\varepsilon_{f k d}
$$

where $x_{f k d}$ is the export revenue (export quantity $x$ export price) that firm $f$ gets from selling product $k$ in destination $d ; p_{f k d}$ is the export price, $\gamma_{k d}$ is a product + destination fixed effect and $\varepsilon_{f k d}$ is the disturbance term. Since we control for product+destination fixed effects in Eq. 1, we can measure precisely the association between export revenues and export prices. If exporters compete on costs, we will expect a $\beta$ coefficient $<0$; in contrast, if firms compete on quality, we will expect a $\beta$ coefficient $>0$. We estimate Eq. (1) with ordinary least squares (OLS), clustering errors by firms.

In the second empirical analysis, we test whether firms obtain larger export revenues from their high-price products or their low-price products. To compare the price across products, following Manova and $\mathrm{Yu}$ (2017), first, we demean export prices:

$$
\bar{p}_{f k d}=\frac{p_{f k d}}{\left(\sum_{f} p_{f k d} / n\right)}
$$

where $\bar{p}_{f k d}$ is the demeaned export price of product $k$ exported by firm $f$ to destination $d$. The denominator in Eq. (2) is the average export price of Spanish exporters of product $k$ to destination $d ; n$ is the number of Spanish exporters of product $k$ to destination $d$.

Once we calculate the demeaned export price, we estimate the following regression equation:

$$
\ln x_{f k d}=\alpha \bar{p}_{f k d}+\gamma_{f d}+\varepsilon_{f k d}
$$

Since Eq. (3) introduces a firm+destination fixed effect, we can measure precisely whether firms obtain larger export revenues in their low export price products or in their high export price products. ${ }^{3}$ We estimate Eq. (3) with OLS, clustering errors by products.

\footnotetext{
${ }^{2}$ Other studies, such as Verhoogen (2008) and Crozet et al. (2012) also develop models where firms compete on quality. Hallak and Sivadasan (2013) take an eclectic approach arguing that firms have two types of productivity: (i) process productivity and (ii) product productivity. The combinations of these productivities explain why two equal-size firms can have a different export status.

${ }^{3}$ Since Eq. (3) includes a firm+destination fixed effect, the $\alpha$ coefficient can only be estimated with a sample that includes firms that sell more than a product in a given destination. Instead, Eq. (1) has a product+destination fixed effect. Therefore, to estimate the $\beta$ coefficient we need at least two firms exporting the same product to the same destination. These firms can be single-product exporters or multiple-product exporters.
} 
Our equations are estimated using data from a single year: 2016. We do not think this affects the general validity of our results. Given that Eq. (1) controls for destination+year fixed effects, it neutralizes all year-specific events, such as the surge of demand for a product in a given destination, that are common for all the exporters of the same product in the same destination. Since Eq. (2) incorporates firm+destination fixed effects, it controls for year-specific changes, such as the expansion of the sales force, that are common to a firm in a destination.

It is important to note that in Melitz (2003) and Baldwin and Harrigan (2011) export prices and export revenues are the result of firms' profit maximization process, and they are determined by fundamentals, such as firm productivity and trade costs. Therefore, the $\beta$ and $\alpha$ coefficients in Eq. (1) and (2) should be interpreted as conditional correlations and not as causal relationships.

\section{Data}

Firm-level export data comes from the Customs and Excise Department of the Spanish Tax Agency. This database, which covers all export transactions, provides the firm's custom identification code, the product at the 8-digit Combined Nomenclature $(\mathrm{CN})$ classification, the destination of the transaction, the free-on-board (FOB) value in euros of the transaction and the exported quantity (in weight metric and/or units). We remove all export transactions with an export value lower than 1,500 euros and belonging to the Harmonized System Classification's chapter 99 (Commodities not elsewhere specified). ${ }^{4}$ We collapse data at the firm-product-destination-year level. Export prices (or unit values) are calculated as the ratio of value over quantity.

Table 1. Summary statistics of the estimation samples, 2016.

\begin{tabular}{lrr}
\hline \hline Number of firms & All firms & $\begin{array}{r}\text { Multiproduct in } \\
\text { destination firms }\end{array}$ \\
\hline Total exports (billion euros) & 73939 & 33105 \\
\% of all merchandise exports & 243 & 196 \\
Median exports per firm (euros) & $95 \%$ & $77 \%$ \\
Median products exported by firm & 48601 & 230837 \\
Median destination served by an exporter & 2 & 4 \\
\hline \hline
\end{tabular}

Source: Authors' calculations from Customs.

Table 1 provides some summary statistics of the samples we use in the first and second analyses. Column All firms provides the summary statistics for all exporters included in the database in 2016. That year, 73939 firms exported a total amount of 243 billion euros, which represented $95 \%$ of all merchandise exports in Spain. ${ }^{5}$ The median exporter had an export revenue of 48,601 euros, exported 2 products, and served one market only. In the column titled Multiproduct in destination firms, we provide summary statistics for the sample used to test whether firms get larger export revenues from their low-price products or their high-price products. The total number of firms is reduced by $52 \%$. However, the reduction in total exports is much lower: $19 \%$. The value of exports in this second sample still represents $77 \%$ of all merchandise exports. The median exporter had a larger export revenue, 230,837 euros, exported more goods, 4, and

\footnotetext{
${ }^{4}$ Firms with monthly exports to EU countries below this threshold for a given product are not obliged to report their transactions to the Spanish Tax Revenue Agency.

${ }^{5}$ According to the Spanish Statistical Institute (INE) 254 billion euros of goods were exported by Spain in 2016.
} 
served 2 foreign markets. This comparison confirms the positive association between the value of exports and the number of exported products and destinations served by a firm (Bernard et al., 2007).

\section{Results}

Table 2 presents the results of estimating Eq. (1), where we analyze whether larger export revenues are associated with a lower export price. In Column (1) we present the results when Eq. (1) is estimated with All firms' sample. The export price coefficient is negative and very precisely estimated. This coefficient indicates a negative association between export prices and export revenues: a 10\% increase in the export price leads to a $1 \%$ drop in export revenues. This result suggests that top Spanish exporters follow a cost-based strategy.

Table 2. Differences in export revenues and export prices across firms.

\begin{tabular}{lrrr}
\hline \hline & $(1)$ & $(2)$ & $(3)$ \\
& All & Manufactures & Rauch's classification \\
\hline Export price $(\log )$ & $-0.128^{* * *}$ & $-0.127^{* * *}$ & $-0.193^{* * *}$ \\
& $(0.008)$ & $(0.008)$ & $(0.010)$ \\
Export price $(\log ) *$ Differentiated & & & $0.073^{* * *}$ \\
& & & $(0.013)$ \\
\hline \# observations & 737692 & 701952 & 594597 \\
Adj. R-squared & 0.209 & 0.202 & 0.210 \\
\hline \hline
\end{tabular}

Note: All estimations include product+destination fixed effects. Standard errors clustered by firm in parentheses. $* * *$ statistically significant at $1 \%$.

Some products have more scope for vertical differentiation than others (Khandelwal, 2010). For example, manufactures, on average, allow for a larger range of quality varieties than commodities and extractable goods. In Column (2), we estimate Eq. (1) using a sample of strictlydefined manufactures. ${ }^{6}$ The coefficient for export price is almost identical to the one reported in Column (1), indicating that the negative relationship between export revenues and export prices is robust to focusing on strictly-defined manufactures. In Column (3), we distinguish differentiated and non-differentiated goods using Rauch's (1999) classification. To test whether the negative effect of export prices on export revenues is smaller for differentiated products, we interact the export price with a dummy variable that takes the value of one if the product is differentiated and zero otherwise. The interaction coefficient is positive and statistically significant. This coefficient indicates that an increase in export prices would have a smaller negative effect on export revenues if the product was differentiated.

In our second empirical analysis, we measure the relation between export prices and export revenues within firms. We want to examine whether firms obtain larger export revenues in their low-price products or in their high-price products. The results of estimating Eq. (3) are reported in Table 3, which follows the same structure as Table 2. We find that the (demeaned) export price coefficient is negative and very precisely estimated. This result indicates that firms obtain lower export revenues in their high-price products. According to the coefficient in Column (1), a $10 \%$ rise in the export price would lead to a $1 \%$ reduction in export revenues. The export price coefficient is the same for strictly-defined manufactures. The negative effect of export prices

\footnotetext{
${ }^{6}$ Since the Harmonized System classification includes within manufacturing products that have a large raw material component (e.g. copper waste), we use the classification of strictly-defined manufactures developed by Daruich et al. (2016). This classification appears in the Appendix A of their paper.
} 
on export revenues is moderated if the product is differentiated, although the coefficient is not precisely estimated. Note that the specification in Column (3) includes an additional independent variable: Differentiation. We need to introduce this dummy variable since the fixed effects in Eq. 3 no longer control for products. ${ }^{7}$ The Differentiation coefficient shows that firms obtain larger export revenues in differentiated products than in non-differentiated products.

Table 3. Export prices and export revenues within firms.

\begin{tabular}{lrrr}
\hline \hline & $(1)$ & $(2)$ & $(3)$ \\
& All & Manufactures & $\begin{array}{r}\text { Rauch's } \\
\text { classification }\end{array}$ \\
\hline Export price $(\log )$ & $-0.099^{* * *}$ & $-0.099^{* * *}$ & $-0.118^{* * *}$ \\
Differentiated & $(0.006)$ & $(0.006)$ & $(0.011)$ \\
& & & $0.105^{* * *}$ \\
Export price $(\log ) *$ Differentiated & & & $(0.032)$ \\
& & & 0.018 \\
\# observations & & & $(0.012)$ \\
Adj. R-squared & 652873 & 609003 & 510684 \\
\hline \hline
\end{tabular}

Note: All estimations include firm+destination fixed effects. Standard errors clustered by products in parentheses. $* * *$ statistically significant at $1 \%$.

Table 4. Rank export revenues and rank export prices within firms.

\begin{tabular}{lrrr}
\hline \hline & $(1)$ & $(2)$ & $(3)$ \\
& All & Manufactures & $\begin{array}{r}\text { Rauch's } \\
\text { classification }\end{array}$ \\
\hline Rank export price & $-0.098^{* * *}$ & $-0.099^{* * *}$ & $-0.126^{* * *}$ \\
Differentiated & $(0.014)$ & $(0.014)$ & $(0.028)$ \\
Rank export price*Differentiated & & & 0.417 \\
& & & $(0.258)$ \\
\# observations & & & 0.024 \\
Adj. - squared & & & $(0.027)$ \\
\hline \hline
\end{tabular}

Note: All estimations include firm+destination fixed effects. Standard errors clustered by products in parentheses. ${ }^{* * *}$ statistically significant at $1 \%$.

To test the robustness of our results, following Manova and Yu (2017), for each firm and destination, we sort products, in descending order, by their revenue, giving a rank equal to 1 to the top product. We apply the same procedure to rank products by export prices. Now, the dependent variable in equation (3) is the rank of the product and the independent variable the rank of the export price. The new estimates are reported in Table 4 . We find that the rank export price coefficient is negative and statistically significant, confirming the negative association between

\footnotetext{
${ }^{7}$ Table 2 does not report the differentiation dummy variable coefficient. Eq. (1) introduces product+destination fixed effects. Given that the differentiation category does not vary within products, this coefficient cannot be estimated.
} 
export prices and export revenues. According to the coefficient in Column (1), an increase in 10 positions in the rank of export prices leads to a drop in one position in the export revenue rank. Results are very similar for strictly-defined manufactures. We do not find that differentiation attenuates the negative effect of a higher rank in export prices on the export revenue rank. Differentiated products do not lead to higher positions in the export revenue rank either.

\section{Conclusion}

Using Spanish firm-level export data for 2016, we analyze whether firms that obtain large revenues in export markets follow a cost-based or quality-based strategy. We find that firms that set lower export prices obtain larger export revenues. This negative association is estimated once we control for very detailed product and destination-level differences. We show that the negative effect of export prices on export revenues is attenuated, but not eliminated, if firms export products that have more room for quality differentiation. To neutralize firm-level idiosyncrasies, we also examine whether firms obtain larger export revenues from their low-price products or their high-price products. In line with our first results, we find that firms obtain larger export revenues from their low-price products.

If firms follow a cost-based strategy in export markets, it is important that they can purchase their inputs at competitive prices. Therefore, policies should seek to foster competition in the markets in which these inputs are traded. On the other hand, some of our results suggest that specializing in products that provide scope for vertical differentiation allow firms to attenuate the negative effects of higher export prices on export revenues.

\section{Acknowledgements}

We thank the Department of Customs and Excise of the Spanish Tax Agency (AEAT) for providing the essential information for this paper. We gratefully acknowledge financial support from the Spanish Ministry of Economy and Competitiveness (MINECO ECO2016-79650-P and ECO2015-68057-R, co-financed with FEDER) and the Basque Government Department of Education, Language policy and Culture (IT629-13).

\section{References}

Baldwin, R., and Harrigan, J. (2011) Zeros, quality, and space: Trade theory and trade evidence, American Economic Journal: Microeconomics, 3(2), 60-88.

Bastos, P., and Silva, J. (2010) The quality of a firm's exports: Where you export to matters, Journal of International Economics, 82(2), 99-111.

Bernard, A. B., Jensen, J. B., Redding, S. J., and Schott, P. K. (2007) Firms in international trade, Journal of Economic Perspectives, 21(3), 105-130.

Crozet, M., Head, K., and Mayer, T. (2012) Quality sorting and trade: Firm-level evidence for French wine, The Review of Economics and Statistics, 79(2), 609-644.

Daruich, D., Easterly, W., and Reshef, A. (2016) The surprising instability of exports specializations, NBER Working Paper 22869, National Bureau of Economic Research.

Görg, H., Halpern, L., and Muraközy, B. (2017) Why do within-firm-product export prices differ across markets? Evidence from Hungary, The World Economy, 40 (6), 1233-1246.

Hallak, J. C., and Sivadasan, J. (2013) Product and process productivity: Implications for quality choice and conditional exporter premia, Journal of International Economics, 91 (1), 53-67

Harrigan, J., Ma, X., and Shlychkov, V. (2015) Export prices of U.S. firms, Journal of International Economics, 97(1), 100-111. 
Khandelwal, A. (2010) The long and short (of) quality ladders, The Review of Economic Studies, 77(4), 1450-1476.

Manova, K., and Yu, Z. (2017) Multi-product firms and product quality, Journal of International Economics, 109 (November), 116-137.

Manova, K., and Zhang, Z. (2012). Export prices across firms and destinations, The Quarterly Journal of Economics, 127(1), 379-436.

Martin, J. (2012) Markups, quality and transport costs, European Economic Review, 56(4), 777 791.

Melitz, M. J. (2003) The impact of trade on intra-industry reallocations and aggregate industry productivity, Econometrica, 71(6), 1695-1725.

Rauch, J.E. (1999) Networks versus markets in international trade, Journal of International Economics, 48(1), 7-35.

Verhoogen, E. A. (2008) Trade, quality upgrading, and wage inequality in the Mexican manufacturing sector, The Quarterly Journal of Economics, 123(2), 489-530. 